\title{
PERAN KOMITMEN DALAM MENGHINDARI IHTIKAR SEMBAKO di PASAR KREMBANGAN SURABAYA (Studi Pada Mahasiswa Program Studi Ekonomi Islam Fakultas Ekonomi dan Bisnis Universitas Airlangga) ${ }^{1)}$
}

\author{
Mirzha Ayunirraga \\ Program Studi S1 Ekonomi Islam-Fakultas Ekonomi dan Bisnis-Universitas Airlangga \\ Email : tembok_bata@ymail.com \\ Qudsi Fauzi \\ Departemen Ekonomi Syariah-Fakultas Ekonomi dan Bisnis-Universitas Airlangga \\ Email : Qudsi.Fauzi@gmail.com
}

\begin{abstract}
:
Dealing transaction in sharia Islam is main purpose to every muslims as muammalah (worship) behavior acted. The merchants commintment is basic point to establish ethics and muslim merchants behavior according to Rasulullah SAW taught to avoid prohibited dealing transactions in sharia Islam. One of the forbidden form in Islamic dealing transaction is intikar (accumulated foodsupplies). The main point of these research to knows understanding behavior commitment of muslim merchants in Krembangan traditional market Surabaya to avoid the forbidden one in Islam, which is Ihtikar (accumulated foodsupplies). The research method used qualitative within descriptive study case. The informant determine by purposive sampling. Data samples are collected by semi-structured interview. The results of this research shown that was in generally, muslim merchants has understood commitment behavior acts within sincerity intention, hard work, truth, unity, and khiar (determination) principles to avoid intikar.
\end{abstract}

Keywords: Commitment, Ihtikar, Krembangan Traditional Market Surabaya, Merchant

\section{PENDAHULUAN}

Dalam berdagang, tataran nilai kehidupan yang diajarkan oleh Islam, seorang pedagang sering terbentur oleh berbagai kepentingan dalam menjalankan kegiatan usahanya, sehingga dapat melalaikan kegiatan

a. Komitmen berasal dari kata Latin "Committer" yang berarti menggabungkan, mempercayai, dan mengerjakannya.

b. Komitmen juga merupakan sikap yang menuntun atau menengahi respon nyata seseorang atau niat perilaku seseorang terhadap sesuatu ibadahnya (sudarsono, 2000:26). Maka dari itu, manusia dituntut memiliki sebuah komitmen di setiap tindakan dan tujuan dalam hidupnya (Huzaimah, 1997:62).

Beberapa ini adalah beberapa definisi komitmen menurut Partina (2005:1284), sebagai berikut:

c. Komitmen adalah sesuatu yang membuat seseorang membulatkan hati, bertekad, berjerih payah, berkorban, dan bertanggung jawab demi mencapai tujuan.

Komitmen mudah diucapkan, namun lebih sukar untuk dilaksanakan. Melaksanakan sesuatu dengan penuh

\footnotetext{
1) Jurnal ini merupakan bagian dari skripsi dari Mirzha Ayunirraga, NIM : 041014168, yang diuji pada 29 desember 2015.
} 
Ayunirraga, et al/Jurnal Ekonomi Syariah Teori dan Terapan Vol. 3 No. 7 Juli 2016: 533-548; PERAN KOMITMEN DALAM MENGHINDARI IHTIKAR SEMBAKO di PASAR KREMBANGAN SURABAYA (Studi Pada Mahasiswa Program Studi Ekonomi Islam Fakultas Ekonomi dan Bisnis Universitas Airlangga)

tanggung jawab adalah salah satu sikap komitmen dalam berdagang, dan tidak hanya berbicara pada tataran perilaku seorang penjual, tetapi juga menyangkut kredibilitas dari produk atau jasa yang ditawarkan, karena secara tidak langsung komitmen dalam berdagang akan berdampak pada hasil penjualan itu sendiri (Harindyatama, 2013:5).

Dalam hal ini, para Ahli Fiqih yang dikutip oleh Huzaimah (1997:239) berpendapat, bahwa intikar (penimbunan) menjadi terlarang atau diharamkan, apabila terdapat syarat sebagai berikut:

1. Penimbunan itu dilakukan pada saat manusia sangat membutuhkan barang yang ia timbun, semisal; sembako, bahan bakar, tanah, dan barang kebutuhan lainnya. Dalam hal ini, bila barang yang dimiliki pedagang tidak menyangkut kebutuhan utama (primer) konsumen, maka tidak dianggap sebagai penimbunan, karena tidak mengakibatkan kesuitan bagi manusia.

2. Barang yang diperjual-belikan adalah bahan pokok yang ditimbun dari suatu tanggungan persediaan nafkah untuk dirinya sendiri dan keluarganya dalam tenggang waktu selama satu tahun.

3. Barang-barang yang ditimbunnya itu dalam usaha menunggu saat naiknya harga, sehingga barang tersebut dapat dijual dengan harga yang lebih tinggi, dan dapat memberatkan konsumen tersebut.
Ketiga syarat tersebut, dapat dianalisa dari aspek keharamannya adalah terhadap barang kelebihan nafkah dari dirinya dan keluarganya dan keluarganya dalam masa satu tahun, yang berarti bila ia menimbun barang konsumsi untuk kebutuhan hidup keluarga dan dirinya selama setahun tidaklah diharamkan, sebab hal ini adalah wajar untuk menghindari kesulitan ekonomi di musim paceklik, kemudian pengharaman terhadap barang dengan dalih ingin memperoleh keuntungan yang berlipat ganda, sebab bila tidak ditimbun, keuntungan yang didapatkan cenderung kecil, dan penimbunan ini dapat merusak harga dipasaran, yaitu dari harga yang rendah menjadi harga yang lebih tinggi, diutamakan sebagai bahan kebutuhan primer (sembako), dan tidak menyinggung tentang kebutuhan tersier (pelengkap) (Huzaimah, 1997:241).

Dalam penjelasan maksud diatas berkaitan erat dengan fenomena yang biasa terjadi di pasar tradisional, yaitu; kebutuhan bahan pokok cenderung meningkat tajam setiap mendekati hari raya, rencana kenaikan bahan bakar, penerapan pembatasan stok bahan bakar bersubsidi yang melanda hampir di seluruh negara ini, bahkan hingga penyaluran pasokan kebutuhan bahan pokok (sembako), dan produk lainnya yang telah tidak layak pakai, menyebabkan hampir setiap bulan sekali harga sembako di pasar cencerung tidaklah stabil. Hal tersebut 
Ayunirraga, et al/Jurnal Ekonomi Syariah Teori dan Terapan Vol. 3 No. 7 Juli 2016: 533-548; PERAN KOMITMEN DALAM MENGHINDARI IHTIKAR SEMBAKO di PASAR KREMBANGAN SURABAYA (Studi Pada Mahasiswa Program Studi Ekonomi Islam Fakultas Ekonomi dan Bisnis Universitas Airlangga)

memicu hilangnya komitmen sebagian pihak tertentu untuk melakukan kecurangan demi mendapat keuntungan yang besar. Dengan stok kebutuhan yang terbatas, warga terpaksa harus mengeluarkan ongkos besar untuk membeli harga barang yang melambung, karena permintaan tinggi. Namun, persediaan barang yang terbatas di pasar dapat memicu penimbunan.

Berdasarkan uraian yang telah dijelaskan, maka peneliti dapat merumuskan masalah penelitian sebagai berikut; Bagaimanakah seorang pedagang muslim berkomitmen dalam menghindari ihtikar sembako di pasar Krembangan Surabaya?

Penelitian ini bertujuan untuk mengetahui komitmen pedagang muslim dalam menghindari intikar sembako, dengan strategi studi kasus di Pasar Krembangan Surabaya.

\section{LANDASAN TEORI}

Peran komitmen berperilaku seorang pedagang didalam Islam adalah sebagai motif ikatan kesadaran untuk selalu taat dan setia sebagai naluri dasar untuk mewujudkan apa yang telah dikrarkan dengan penuh tanggung jawab sesuai yang digariskan oleh Al-Qur'an, sehingga pedagang muslim dituntut tidak sekedar mengejar keuntungan dunia semata, tetapi selalu berorientasi pada masa depan (akhirat) (Ali, 2000:27),

Komitmen berdagang dapat disimpulkan sebagai sikap yang muncul atas kehendak secara langsung dan kesadaran sendiri terhadap perilaku manusia dalam pemenuhan kebutuhan, sehingga Islam memandang sebuah komitmen kerja dalam berdagang yang didasarkan pada prinsip-prinsip iman tidak hanya menunjukkan fitrah seorang muslim, melainkan sekaligus meninggikan martabat dirinya sebagai hamba Allah yang didera kerinduan untuk menjadikan dirinya sebagai sosok yang dapat dipercaya, menampilkan dirinya sebagai manusia yang amanah, dan sebagai seorang khalifah (pemimpin) yang menunjukkan sikap ketauhidan seorang manusia kepada Sang Penciptanya. Hal ini dapat ditemukan pada firman Allah, Surat At-Taubah ayat 111 berikut:

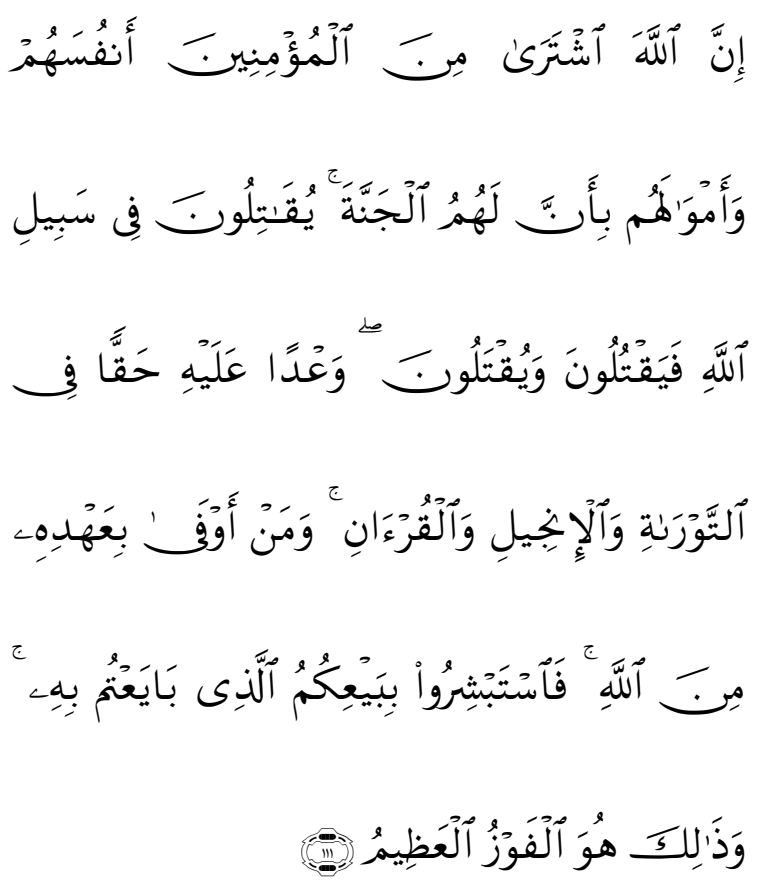

Artinya: "Sesungguhnya Allah telah membeli dari orang - orang mukmin diri dan harta mereka dengan memberikan 
Ayunirraga, et al/Jurnal Ekonomi Syariah Teori dan Terapan Vol. 3 No. 7 Juli 2016: 533-548; PERAN KOMITMEN DALAM MENGHINDARI IHTIKAR SEMBAKO di PASAR KREMBANGAN SURABAYA (Studi Pada Mahasiswa Program Studi Ekonomi Islam Fakultas Ekonomi dan Bisnis Universitas Airlangga)

surga untuk mereka, mereka berperang pada jalan Allah, lalu mereka membunuh atau terbunuh. (Itu telah menjadi) janji yang benar dari Allah di dalam Taurat, Injil dan Al Quran. Dan siapakah yang lebih menepati janjinya (selain) daripada Allah? Maka bergembiralah dengan jual beli yang telah kamu lakukan itu, Itulah kemenangan yang besar"

Pada ayat tersebut, setiap manusia yang bekerja secara baik dengan niat ketauhidan hanya kepada Allah, maka telah dijanjikan suatu kemenangan berupa kehidupan yang baik di surga, sedangkan barang siapa yang enggan bekerja dalam menunaikannnya nilai ketauhidan sebagai seorang hamba Allah, dan lebih suka mencari keuntungan dunia, maka ditantang oleh Al-Qur'an dengan membuat satu ayat yang tidak mengenal kerugian ataupun penipuan (Ali, 2000:25). hal ini sesuai dengan firman Allah pada surat an-Nahl ayat 90 berikut ini:

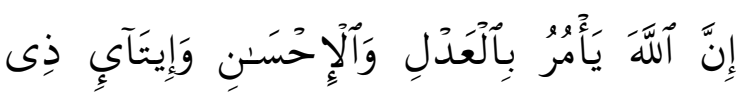

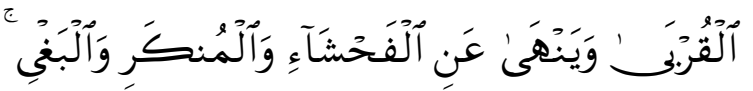

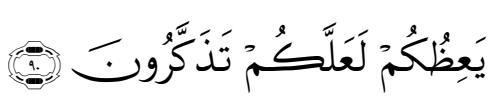

Artinya: "Sesungguhnya Allah menyuruh (kamu) Berlaku adil dan berbuat kebajikan, memberi kepada kaum kerabat, dan Allah melarang dari perbuatan keji, kemungkaran dan permusuhan. Dia memberi pengajaran kepadamu, agar kamu dapat mengambil pelajaran".

$$
\text { Menurut As-Sayyid }
$$
komitmen mengakibatkan perilaku seorang pedagang lebih efisien dalam membangun akhlaq mahmudah (akhlaq yang terpuji) dan meninggalkan akhlaq mazmumah (akhlaq yang tercela). Komitmen tersebut memiliki beberapa bentuk dasar, yaitu; niat ikhlas (sosial), kerja keras, kesatuan (tauhid), kebenaran (keadilan), dan kebebasan berkehendak. (Anwar, 2007:32).

Menurut prinsip Hukum Islam, yang dikutip oleh (Ibrahim, 1986:144), sesuatu yang dihalalkan Allah untuk memilikinya, maka halal pula yang menjadi obyek perdagangan, demikian pula halnya segala bentuk barang yang diharamkan untuk memilikinya, maka haram pula memerdagangkannya. Di samping itu, dalam ketentuan hukum Islam, bahwa barang itu pada dasar nya halal, akan tetapi, karena sikap serta perbuatan para pelakunya, maka usahanya itu menjadi haram, yaitu; penimbunan barang dagangan, sebab penimbunan yang dilakukan itu bertujuan untuk mencari keuntungan yang lebih banyak, terutama pada saat harga itu naik.

Menurut Syaikh Abdurrahman (2007:87), terdapat beberapa definisi yang diberikan oleh ulama tentang intikar. Adapun beberapa definisi yang menurut ulama: 
Ayunirraga, et al/Jurnal Ekonomi Syariah Teori dan Terapan Vol. 3 No. 7 Juli 2016: 533-548; PERAN KOMITMEN DALAM MENGHINDARI IHTIKAR SEMBAKO di PASAR KREMBANGAN SURABAYA (Studi Pada Mahasiswa Program Studi Ekonomi Islam Fakultas Ekonomi dan Bisnis Universitas Airlangga)

1. Muhammad bin Ali Syaukani, mendefinisikan intikar sebagai penimbunan atau penahanan barang dagangan dari peredarannya.

2. Muhammad bin Muhammad Ghazali, mendefinisikan intikar sebagai penyimpanan barang dagangan oleh penjual makanan, untuk menunggu melonjaknya harga, dan penjualannya dilakukan, ketika harga naik.

3. Ulama mazhab Maliki, menyatakanbahwa intikar adalah penyimpanan barang oleh produsen baik makanan, pakaian, dan segala jenis barang yang dibutuhkan masyarakat luas, karena dapat berpotensi merusak pasar.

Dari ketiga definisi tersebut, tampaknya memiliki persamaan, yaitu adanya upaya pedagang untuk menimbun barang dagangan, agar langka di pasaran, kemudian hendak dijual pada saat harga barang tersebut melonjak naik. Jenis barang yang tidak boleh ditimbun berupa barang yang dibutuhkan masyarakat, misalnya; bahan pokok, BBM, sumber daya, air, dan segala macam kebutuhan yang dibutuhkan oleh masyarakat luas, akan tetapi dalam ketiga definisi tersebut juga memiliki perbedaan dalam menimbun jenis produk yang disimpan atau ditimbun di gudang, sekalipun ketiga definisi itu memberikan pengertian yang sama, yaitu menimbun jenis barang yang diperlukan masyarakat dengan tujuan menjualnya, ketika permintaan telah melonjak, barang itu baru dipasarkan (Syafi'i, 2006:124).

Menimbun (ihtikar), menurut Imam Duraini, tidak saja menyangkut komoditi, tetapi juga manfaat suatu komoditi, dan balikan jasa dari para pemberi jasa, dengan syarat memanipulasi penjualan yang dilakukan para pedagang dan pemberi jasa dapat membuat harga pasar tidak stabil, padahal komoditi, manfaat, atau jasa itu sangat diperlukan oleh masyarakat, sehingga mengakibatkan melonjaknya harga pasar secara drastis, disebabkan persediaan terbatas atau stok barang hilang sama sekali dari pasar (Ibrahim, 1986:224).

Di samping itu, perlindungan terhadap barang yang diperdagangkan dari kemungkinan cacat atau tidak sesuai dengan perilaku yang ditentukan pada saar aqad (transaksi), serta perlindungan terhadap kepentingan konsumen agar tidak dirugikan dan tidak terjadi kekecewaan di kemudian hari sangat dipertimbangkan dalam hukum Islam, sedangkan harga dan keuntungan yang diminta, dapat dirumuskan oleh kedua belah pihak dengan dasar suka sama suka (an taradhin) dalam suatu transaksi, dan didukung oleh bukti tertulis, persaksian, ataupun jaminan sesuai Surat Al-Baqarah, ayat 279 , Allah berfirman: 
Ayunirraga, et al/Jurnal Ekonomi Syariah Teori dan Terapan Vol. 3 No. 7 Juli 2016: 533-548; PERAN KOMITMEN DALAM MENGHINDARI IHTIKAR SEMBAKO di PASAR KREMBANGAN SURABAYA (Studi Pada Mahasiswa Program Studi Ekonomi Islam Fakultas Ekonomi dan Bisnis Universitas Airlangga)

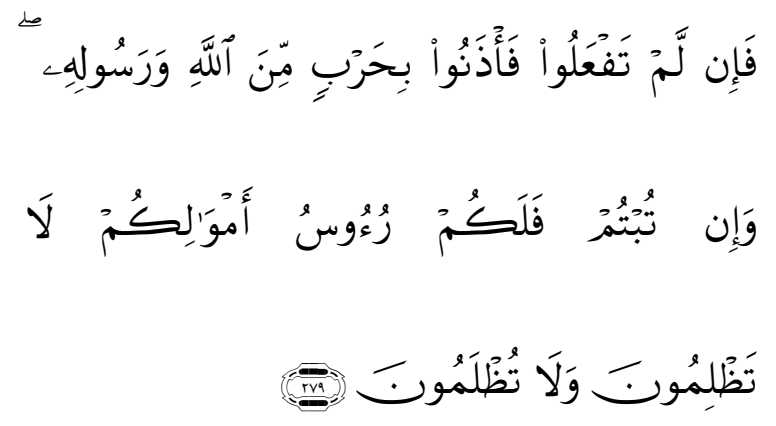

Artinya: "Maka jika kamu tidak mengerjakan (meninggalkan sisa riba), Maka ketahuilah, bahwa Allah dan Rasul-Nya akan memerangimu. Dan jika kamu bertaubat (dari pengambilan riba), maka bagimu pokok hartamu, Kamu tidak Menganiaya dan tidak (pula) dianiaya"

Oleh karenanya dalam ayat diatas, setiap bentuk dan tindakan ekonomi yang di dalamnya mengandung Ihtikar (menimbun ataupun monopoli), dharar (menyesatkan), gharar (tipuan), haraj (paksaan), dan najsy (menggoyang harga supaya tinggi melampau batas), dilarang dalam Islam (Rahman, 1995:199).

Menurut Ali (2000:114), menyatakan bahwasannya hal tersebut membuat kaum penimbun lebih terkutuk di sisi Allah, karena dua hal berikut:

1. Penimbun kebutuhan pokok masyarakat (Seorang ahli fiqih yang bernama Abu Yusuf, mengatakan bahwa segala apa yang membahayakan manusia, apabila disimpan atau ditimbun itu juga diharamkan, baik itu berupa bahan pakaian, emas, padi, dan lain sebagainya)lebih berbahaya dari pada penimbunan yang dilakukan oleh suatu kaum yang suka menjalankan riba, karena kaum tersebut hanyalah menimbun vang saja.

2. Bahaya yang ditimbulkan oleh penimbun kebutuhan pokok masyarakat amatlah fatal, karena seluruh rakyat akan merasakan penderitaannya. Berbeda dengan riba, hanya golongan tertentu saja yang merasakan penindasannya, yaitu golongan yang membutuhkan capital (modal).

Menurut Ali (2000:115), mengatakan bahwa sesuatu yang dapat ditimbun itu dilarang, karena menyebabkan kesulitan pada konsumen sebagai pengguna barang merupakan suatu tindak kejahatan. Dengan ditahannya kebutuhan pangan tersebut, maka barang kebutuhan pokok tersebut hilang dari peredaran, padahal masyarakat sangat membutuhkannya. Setelah situasi sudah sampai ke taraf ini, maka para penimbun dan para tengkulak akan menjual barangbarangnya dengan harga yang amat tinggi, akibat ulah mereka, maka beban yang dipikul oleh masyarakat makin bertambah. Oleh karena itu, sebagai akibat dari perbuatan menimbun dalam kegiatan perdagangan, keseimbangan pemerataan akan kacau dalam tubuh 
Ayunirraga, et al/Jurnal Ekonomi Syariah Teori dan Terapan Vol. 3 No. 7 Juli 2016: 533-548; PERAN KOMITMEN DALAM MENGHINDARI IHTIKAR SEMBAKO di PASAR KREMBANGAN SURABAYA (Studi Pada Mahasiswa Program Studi Ekonomi Islam Fakultas Ekonomi dan Bisnis Universitas Airlangga)

masyarakat, karena para tengkulak terus menyedot sebagian besar kekayaan rakyat tanpa mengenal belas kasihan, hal tersebut memicu harga bahan pokok di pasaran akan mengalami kenaikan yang drastis, dan keadaan pasar menjadi guncang, karena tidak adanya stabilitas harga, sehingga dalam situasi yang labil ini, masyarakat akan termotivasi melakukan pembelian barang yang lebih dari kebutuhannya, sekalipun harga barang amat mahal, karena takut habis. Perilaku tersebut membuat fakir miskin sebagai korban utama, karena mereka tak dapat meraih kebutuhan pokoknya, disebabkan kemampuan daya beli mereka yang terbatas. Perbuatan penimbunan barang yang demikian dilarang oleh Allah dalam Surat Al-Israa, ayat 35, sebagai berikut:

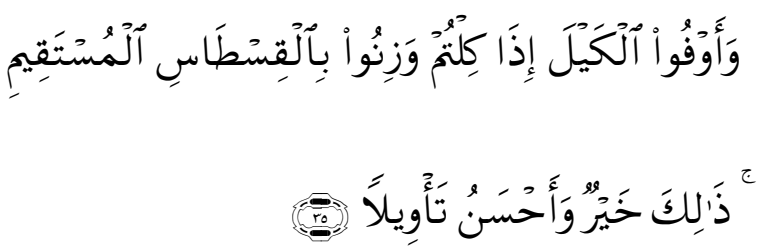

Artinya: "Dan sempurnakanlah takaran apabila kamu menakar, dan timbanglah dengan neraca yang benar. Itulah yang lebih utama (bagimu), dan lebih baik akibatnya"

Atas dasar ayat diatas, para ulama juga banyak pendapat, bahwa yang haram ditimbun, bukan hanya barang komoditas makanan pokok sehari-hari suatu penduduk saja, melainkan komoditi yang kalau hal tersebut sulit didapatkan, maka hal itu bisa menyebabkan kesengsaraan bagi masyarakat, bahkan
Ulama Malikiyah berpendapat, bahwa haramnya menimbun tidak hanya pada bahan pokok saja, melainkan semua barang. Melakukan penimbunan dengan tujuan menjualnya setelah terjadi lonjakan harga, pemerintah berhak melakukan pengawasan terhadap pasar, tindakan patokan harga oleh pemerintah kepada harga harus memenuhi persyaratan syariah, yaitu (Huzaimah, 1997:395):

a. Komoditas atau jasa itu sangat dibutuhkan masyarakat luas.

b. Terbukti bahwa produsen, pedagang, dan spekulan melakukan manipulasi, spekulasi, penimbunan, atau rekayasa keji dalam menentukan harga komoditas dan tarif jasa mereka.

c. Pemerintah tersebut adalah pemerintah yang adil.

d. Pihak pemerintah harus melakukan studi kelayakan harga dan kajian pasar, dengan berkonsultasi dengan kepada para ahlinya.

e. Pematokan harga tersebut dengan mengacu kepada prinsip keadilan bagi semua pihak.

f. Pemerintah secara proaktif harus melakukan kontrol dan pengawasan yang kontinyu terhadap kegiatan pasar, baik menyangkut stok barang, harga, indiaktor, dan variabel lainnya, sehingga tidak terjadi penimbunan barang dan monopoli jasa yang berakibat kesewenangan harga.

Hukum haramnya menimbun barang, karena dalam menimbun terdapat 
Ayunirraga, et al/Jurnal Ekonomi Syariah Teori dan Terapan Vol. 3 No. 7 Juli 2016: 533-548; PERAN KOMITMEN DALAM MENGHINDARI IHTIKAR SEMBAKO di PASAR KREMBANGAN SURABAYA (Studi Pada Mahasiswa Program Studi Ekonomi Islam Fakultas Ekonomi dan Bisnis Universitas Airlangga)

tindakan tidak sesuai dengan tujuan syari'at Islam, yaitu; menciptakan kemaslahatan (tahqia al-mashalih), dengan mendatangkan kemanfaatan (jalbul manfa'ah), dan dengan membuang kesengsaraan (daf'ul madlarrah) (Munawar, 1997:288),

\section{METODE PENELITIAN}

Pada penelitian ini penulis menggunakan pendekatan kualitatif jenis studi kasus dengan tujuan untuk mengetahui dan memahami secara mendalam mengenai fenomena yang terjadi dalam komitmen berperilaku pedagang muslim dalam menghindari perilaku menimbun di pasar Krembangan Surabaya. Ruang lingkup penelitian terbatas pada bentuk kejujuran pedagang dalam penimbunan dan penyimpangan permainan harga tersebut di Pasar Krembangan Surabaya sesuai dengan aturan-aturan Islam.

\section{Jenis dan Sumber Data}

Jenis data yang digunakan dalam penelitian ini adalah data primer dan data sekunder. Data primer adalah data yang diperoleh langsung dari sumbernya melalui observasi, wawancara, dan dokumentasi. Data sekunder adalah data yang diperoleh langsung dari sumber kedua, dari data yang dibutuhkan melalui peneliti mengambil data dari peneliti lainnya. Data sekunder digunakan sebagai data pendukung untuk menambah rincian spesifik dan melengkapi data primer (Sugiono, 2010:131). Peneliti memeroleh data dengan cara turun langsung kelapangan dan memperkuatnya dengan bahan teori berdasarkan buku, jurnal, browsing internet, dan penelitian terdahulu yang berkaitan dengan perilaku seorang pedagang pasar pada saat melakukan transaksi perdagangan.

\section{Proses Pengumpulan Data}

Penelitian ini membutuhkan dua jenis data, yaitu; data primer dan data dekunder, prosedur pengumpulan dua jenis data tersebut tentunya tidak sama, data primer diperoleh dengan menggunakan prosedur surat ijin penelitian skripsi secara formal pada bagian akademik Fakultas Ekonomi dan Bisnis (FEB) UNAIR dan PD. Pasar Surya sebagai pelengkap untuk memasuki pasar tradisional yang akan diteliti. Peneliti melakukan kunjungan terlebih dahulu pada Pasar Tradisional Krembangan Surabaya yang akan diteliti untuk menyampaikan maksud dan tujuan peneliti mendatangi tempat tersebut. Setelah mendapatkan daftar nama pedagang yang dapat dijadikan penelitian, peneliti segera menghubungi pedagang tersebut melalui telepon untuk membuat janji pertemuan. Pada tahap ini, peneliti segera menemui pedagang sesai dengan janji yang telah dibuat sebelumnya dengan membawa surat ijin penelitian secara formal dari FEB (Fakultas Ekonomi dan Bisnis) UNAIR dan persetujuan PD. Pasar Surya sebagai pelengkap. 
Ayunirraga, et al/Jurnal Ekonomi Syariah Teori dan Terapan Vol. 3 No. 7 Juli 2016: 533-548; PERAN KOMITMEN DALAM MENGHINDARI IHTIKAR SEMBAKO di PASAR KREMBANGAN SURABAYA (Studi Pada Mahasiswa Program Studi Ekonomi Islam Fakultas Ekonomi dan Bisnis Universitas Airlangga)

Peneliti mendapat data dari hasil observasi langsung dan melakukan wawancara secara semiterstruktur yang mendalam dari pedagang yang menjadi obyek penelitian. Wawancara dilakukan secara terbuka dan peneliti terus melakukan pengembangan pertanyaan ke setiap lokasi objek pebelitian itu berada, tetapi tetap terfokus dan mengarah pada topik bahasan penelitian. Hasil observasi dan wawancara dari objek penelitian akan didokumentasikan sendiri oleh peneliti.

Data sekunder diperoleh dengan prosedur melalui pustaka dan literatur yang berisi bahasan mengenai perilaku pedagang, komitmen pedagang muslim, norma seorang pedagang, dan bentuk aturan yang mengenai penimbunan yang dilakukan pedagang yang diperoleh dengan cara membaca buku di Perpustakaan UNAIR, Perpustakaan daerah, internet, jurnal yang didapat dari pokok bahasan, serta membeli di toko buku yang berada di Surabaya.

\section{Teknik Analisis Data}

Teknik analisis dalam penelitian ini dilakukan dengan metode deskriptif kualitatif. Analisis yang digunakan adalah melihat kejujuran dalam komitmen ukuran timbangan dan harga dalam fenomena penyipangan penimbunan sembako dengan mengembangkan hubungan dari informasi yang diperoleh, yaitu: a. Domain, dilakukan terhadap data yang diperoleh melalui pengamatan deskriptif yang terdapat dalam catatan lapangan.

b. Taksonomi, dilakukan pengamatan wawancara semiterstruktur berdasarkan fokus utama yang sebelumnya telah dipilih oleh peneliti dan memeroleh hasil pengamatan terpilih dimanfaatkan untuk memperdalam data yang telah ditemukan melalui pengajuan sejumlah pertanyaan terfokus.

c. Kompensional, pencarian sistematik berbagai komponen makna yang berhubungan dengan simbol - simbol budaya.

d. Tema, menghubungkan domain secara keseluruhan.

\section{HASIL DAN PEMBAHASAN}

\section{Gambaran Umum Obyek Penelitian}

Obyek penelitian yang digunakan sebagai latar belakang tempat (setting) dalam penelitian ini adalah Pasar Krembangan yang berlokasi di Surabaya.

Surabaya adalah salah satu kota metropolitan dan terbesar kedua di Indonesia yang memiliki luas $326,37 \mathrm{~km} 2$ dan terletak pada $07^{\circ} 21^{\prime}$ ' Lintang Selatan dan $112^{\circ} 36^{\prime} \mathrm{s} / \mathrm{d} 112^{\circ} 54^{\prime}$ Bujjur Timur secara astronomis. Wilayah Surabaya di bagian utara terletak pada pada dataran rendah dengan ketinggian 3-6 meter diatas permukaan laut, wilayah selatan dengan ketinggian 25-50 meter diatas permukaan laut, dan ditengah kota Surabaya memiliki 
Ayunirraga, et al/Jurnal Ekonomi Syariah Teori dan Terapan Vol. 3 No. 7 Juli 2016: 533-548; PERAN KOMITMEN DALAM MENGHINDARI IHTIKAR SEMBAKO di PASAR KREMBANGAN SURABAYA (Studi Pada Mahasiswa Program Studi Ekonomi Islam Fakultas Ekonomi dan Bisnis Universitas Airlangga)

ketinggian 15-19 meter diatas permukaan laut. batas wilayah kota surabaya dibagian Utara dan Timur adalah Selat Madura, bagian Barat dibatasi oleh Kabupaten Gresik, dan sebelah Selatan dibatasi oleh Kabupaten Sidoarjo. Adapun 8 kemiringan lereng tanah berkisar 0-2\% daerah dataran rendah dan $2-5 \%$ daerah perbukitan landai. Kota Surabaya memiliki komposisi batuan yang terdiri dari 4 jenis yang pada dasarnya merupakan tanah liat atau batuan kecil. Surabaya memiliki jenis bentuk tanah berupa alluvial (daerah rawa), selebihnya berupa tanah dengan kadar kapur yang tinggi (perbukitan). Sebagaimana daerah tropis lainnya, Surabaya hanya mengenal musim hujan dan musim kemarau, dengan curah hujan rata-rata $172 \mathrm{~mm}$, dengan suhu berkisar maksimum $30^{\circ} \mathrm{C}$ dan minimum $25^{\circ} \mathrm{C}$ (Elly, 2009:299)

Pemerintahan Kota Surabaya secara administrasi dikepali oleh seorang Walikota, yang juga mengatur koordinasi atas wilayah admistrasi Kecamatan yang dikepalai oleh Camat. Kota Surabaya memiliki Kecamatan sebanyak 31 Kecamatan, 163 Kelurahan, terbagi lagi oleh 1.363 RW (Rukun Warga) dan 8.909 RT (Rukun Tetangga). Kota Surabaya memiliki Topografi yang bersifat dataran rendah dengan 80,72 \% $(25.919,04 \mathrm{Ha})$ dengan ketinggian antara -0,5-5m KPT (Ketinggian Perjengkal Tanah) atau 3 - 8m LWS (Lebar Wilayah Surabaya), sedang sisanya merupakan daerah perbukitan yang terletak dibagian Wilayah Surabaya Barat (12,27\%) dari Surabaya Selatan (6,52\%). Populasi Kota Surabaya sampai dengan bulan Maret 2015 mencapai 3.024.718 jiwa, yang terdiri dari penduduk laki-laki sejumlah 1.148.215 jiwa dan jumlah penduduk perempuan sejumlah 1.876 .503 jiwa, dengan tingkat kepadatan 9.268 jiwa / km2. Pendapatan ekonomi Penduduk Kota Surabaya sebagian besar berasal dari sektor perdagangan barang maupun jasa (Elly, 2009:311)

Pengelolaan pasar tradisional dibentuk sejak akhir tahun 1871 pada jaman kolonial Belanda. Pergantian pengelolaan pasar tradisional di Kota Surabaya berada pada naungan Persatuan Dinas Dagang dibawah pemerintah kota pada awal tahun 1956. Demi mendorong peningkatan pelayanan terhadap kebutuhan publik pada tahun 1982, Persatuan Dinas Dagang berganti menjadi Peusahaan Daerah Pasar. Untuk menunjang moderenitas pada pengelolaan pasar pada tahun 1999 Pemerintah Kota Surabaya menyerahkan hak kelola pasar kepada Perusahaan Daerah Pasar Surya. Pasar tradisional Krembangan merupakan salah satu pasar besar yang berada di utara Kota Surabaya (Alamsyah, 2001:164)

PD. Pasar Surya adalah suatu Badan Usaha Milik Daerah (BUMD) yang bertugas untuk mengawasi pasar tersebut. Berbeda dengan pasar tradisional yang memiliki ciri interaksi tawar menawar, adanya komunikasi antar penjual dan pembeli, 
Ayunirraga, et al/Jurnal Ekonomi Syariah Teori dan Terapan Vol. 3 No. 7 Juli 2016: 533-548; PERAN KOMITMEN DALAM MENGHINDARI IHTIKAR SEMBAKO di PASAR KREMBANGAN SURABAYA (Studi Pada Mahasiswa Program Studi Ekonomi Islam Fakultas Ekonomi dan Bisnis Universitas Airlangga)

bahkan tindakan hutang piutang yang dilakukan penjual dan pembeli. Di pasar modern, pembeli memiliki sedikit interaksi dengan penjual yang menyediakan berbagai macam barang kebutuhan dan jasa bagi pembeli, pembeli memilih barang sendiri, dan pembeli tidak dapat menawar harga yang telah ditentukan oleh penjual tunggal. Pasar tradisional sangat melekat dalam benak dan tetap dibutuhkan oleh masyarakat hingga saat ini, meskipun menjamurnya pasar modern menjadi ancaman tersendiri bagi keberlangsungan pasar tradisional. ancaman tersebut telah menyebabkan terjadi penurunan jumlah pembeli dan banyaknya pedagang di Pasar Krembangan Surabaya yang pindah dari pasar tersebut. Ditambah letaknya yang sangat dekat dari asrama polisi membuat Pasar Krembangan sangat strategis, dikawasan utara Kota Surabaya. Pasar Krembangan Surabaya memiliki 350 stand dengan total pedagang mencapai 523 jiwa, dan luas bangunan $3743\left(\mathrm{~m}^{2}\right)$.

Pasar Krembangan menyediakan beraneka ragam barang yang diantaranya adalah sayuran, ikan, jajan tradisional, buah, kebutuhan sembako, kebutuhan perkakas rumah tangga, pakaian, sandal, tas, obat-obatan, dan lain sebagainya. Perubahan tata kelola Pasar Krembangan yang dilakukan oleh Pemerintah Kota Surabaya melalui PD. Pasar Surya, yang bersama para pedagang dan pembeli disekitar pasar tersebut, telah berhasil merubah kondisi pasar menjadi lebih bersih, nyaman, teratur, dan keamanan saat berbelanja. Dalam melindungi keberlangsungan pasar tradisional salah satunya adalah Pasar Krembangan, Pemerintah membuat aturan yang menyatakan bahwa pasar modern dilarang berdiri kurang lebih 100 meter dari jarak pasar tradisional (Alamsyah, 2001:169).

\section{Deskripsi Hasil wawancara Terhadap Ciri} Komitmen Berperilaku dalam Islam Berdasarkan Konsep Komitmen Bisnis Islami Anwar (2007:32-38)

Berdasarkan dari hasil wawancara dengan 8 informan pedagang muslim dapat dapat dilihat melalui kesimpulan tabel tentang pemahaman prinsip dasar komitmen para informan, sebagai berikut:

Tabel 1.

Hasil Analisa Prinsip Komitmen Pedagang Pasar Muslim Krembangan Surabaya

\begin{tabular}{|c|c|c|c|c|c|}
\hline \multirow{2}{*}{ 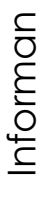 } & \multicolumn{5}{|c|}{ Ciri Berkomitmen Berperilaku dalam Islam } \\
\hline & $\begin{array}{l}\text { Niat } \\
\text { ikhlas }\end{array}$ & $\begin{array}{c}\text { Perilaku } \\
\text { kerja keras }\end{array}$ & $\begin{array}{l}\text { Memiliki } \\
\text { kesatuan }\end{array}$ & Kebenaran & Khiar \\
\hline$X_{1}$ & Memiliki & Memiliki & Memiliki & Memiliki & Memiliki \\
\hline$X_{2}$ & Memiliki & Memiliki & Memiliki & Memiliki & Memiliki \\
\hline$X_{3}$ & Memiliki & Memiliki & Memiliki & Memiliki & Memiliki \\
\hline $\mathrm{X}_{4}$ & Memiliki & Memiliki & Memiliki & Memiliki & Memiliki \\
\hline$X_{5}$ & Memiliki & Memiliki & Memiliki & Memiliki & Memiliki \\
\hline$x_{6}$ & Memiliki & $\begin{array}{l}\text { Kurang } \\
\text { Memiliki }\end{array}$ & Memiliki & Memiliki & Memiliki \\
\hline$X_{7}$ & Memiliki & Kurang & Memiliki & Memiliki & Memiliki \\
\hline
\end{tabular}


Ayunirraga, et al/Jurnal Ekonomi Syariah Teori dan Terapan Vol. 3 No. 7 Juli 2016: 533-548; PERAN KOMITMEN DALAM MENGHINDARI IHTIKAR SEMBAKO di PASAR KREMBANGAN SURABAYA (Studi Pada Mahasiswa Program Studi Ekonomi Islam Fakultas Ekonomi dan Bisnis Universitas Airlangga)

\begin{tabular}{|l|l|l|l|l|l|} 
& & Memiliki & & & \\
\hline$X_{8}$ & Memiliki & Kurang & Memiliki & Memiliki & Memiliki \\
& & Memiliki & & & \\
\hline
\end{tabular}

Sumber : Hasil Penelitian, 2015 (diolah)

Penjelasan dari tabel diatas, disimpulkan berdasarkan hasil simpulan pernyataan para informan yang menerangkan nilai-nilai komitmen berperilaku sebagai berikut; (1) Memiliki prinsip niat ikhlas dalam berperilaku yang baik. Para pedagang yang memiliki niat ikhlas dalam pekerjaannya dalam berperilaku yang baik adalah melayani pembeli dengan sebaik mungkin, memberikan kondisi barang kebutuhan pokok yang dijual berdasarkan keinginan para pembeli dengan sebenar-benarnya, serta menghindari perilaku jual-beli yang dilarang dalam Islam, khususnya ihtikar. Dari 8 informan, semua memiliki prinsip niat ikhlas dalam pekerjaannya dengan baik dalam berdagang; (2) Memiliki prinsip berkehendak bebas (khiar). Dalam ajaran Islam, (khiar) memiliki arti memilih atau menyaring yang terbaik dua hal (atau lebih) dalam perjanjian usaha, meneruskannya atau membatalkannya (Anwar, 2007:36). Dengan demikian, Prinsip berkehendak bebas (khiar) dijelaskan oleh hukum Islam untuk memenuhi kepentingan yang timbul dari transaksi bisnis dalam kehidupan manusia. Prinsip berkehendak bebas (khiar) adalah salah satu dasar dari pembentukan komitmen yang bertujuan untuk menjaga hubungan sosial antar manusia. Hubungan baik antar sesama pedagang adalah salah satu syarat penting dalam mencapai kelancaran suatu usaha. Seorang pedagang harus menjaga hubungan silaturahmi yang baik antar kolega dagang, pedagang lain yang berstatus sebagai saingan dengan mengutamakan kerjasama dalam berbuat kebaikan untuk menghindari berbagai macam tindakan yang menyimpang dalam ajaran Islam, maupun etika bermasyarakat, dan menjaga hubungan tali silaturahmi dengan pelanggan, agar pelanggan merasa nyaman dan puas terhadap pedagang tersebut, sehingga pelanggan tersebut menjadi pelanggan setia. Hubungan silaturahmi kedelapan informan terjalin dengan baik dengan sesama pedagang di Pasar Krembangan Surabaya, termasuk dengan para pelanggan; (3) Perilaku kerja keras. Menurut Naqvi (1993:83-86), perilaku kerja keras memiliki beberapa dasar, yaitu: pertama, pembagian laba bersih sesuai keuntungan yang didapat pada periode tersebut, bukan ditetapkan diawalkan seperti sistem bunga. Kedua, Tanggung jawab terhadap pemberian gaji karyawan sesuai yang telah ditetapkan oleh pemerintah atau sesuai dengan kemampuan pendapatan suatu usaha. Ketiga, Melarang transaksi jual-beli yang dilarang dalam Islam, seperti penimbunan bahan pokok (Ihtikar), Gharar, mengurangi takaran timbangan, dan sebagainya. Dan keempat, memperhitungkan setiap perbuatan sebelum bertindak dengan dasar tanggung jawab atas setiap 
Ayunirraga, et al/Jurnal Ekonomi Syariah Teori dan Terapan Vol. 3 No. 7 Juli 2016: 533-548; PERAN KOMITMEN DALAM MENGHINDARI IHTIKAR SEMBAKO di PASAR KREMBANGAN SURABAYA (Studi Pada Mahasiswa Program Studi Ekonomi Islam Fakultas Ekonomi dan Bisnis Universitas Airlangga)

perbuatannya. Pedagang yang memiliki prinsip kerja keras tentu akan memiliki sifat disiplin dan motivasi kerja yang baik dapat memanfaatkan waktu operasional berdagang secara optimal tanpa harus mengurangi rasa ketaqwaan terhadap Allah. Komitmen dalam perilaku pekerja keras yang dimiliki seorang pedagang adalah tangguh dan pantang menyerah, karena pedagang yang tidak memiliki pribadi tersebut akan tidak bertahan dalam menghadapi berbagai macam tantangan dan resiko dalam pekerjaannya. Terdapat perbedaan jam kerja antar 8 informan secara umum dalam menjalankan waktu operasional berdagang, hal ini terjadi karena informan 6,7 , dan 8 adalah seseorang yang memiliki pekerjaan selain berdagang, sehingga membuat pekerjaannya sebagai seorang pedagang dinilai kurang maksimal. Akan tetapi, terdapat persamaan perilaku yang dilakukan para pedagang untuk mengisi waktu disela-sela usaha dengan berbagai macam kegiatan, diantaranya sebagai berikut: menjalankan ibadah 5 waktu, menonton televisi, berbagi informasi dengan pedagang lain, mendengarkan radio, menghitung jumlah persediaan barang, menghitung jumlah omset yang didapatkan, membaca koran, membersihkan kios, dan menata barang dagangan; (4) Memiliki prinsip kebenaran. Menurut Naqvi (1993:93), sebagai seorang pedagang muslim bentuk komitmen kebenaran berupa 4 hal, yakni: pertama, mengamalkan kejujuran dalam melakukan transaksi bisnis. Kedua, bersikap rela terhadap kedua belah pihak dalam menjaga hubungan sosial sesama manusia. Ketiga, menyisihkan sebagian harta benda untuk berzakat dan bersedekah. Keempat, memberi kesempatan pada pihak yang berhutang. Bentuk prinsip kebenaran yang terdapat dalam wujud komitmen yang dimiliki oleh 8 para informan adalah pemahaman mengenai tindakan yang didasari oleh kejujuran dan istiqamah. Perilaku Istiqamah dapat tercermin oleh perilaku para pedagang muslim dalam menjalankan pekerjaan secara konsisten walaupun menghadapi resiko dan halangan tanpa harus meninggalkan prinsip kejujuran dan kebajikan. Semua 8 pedagang muslim yang diwawancari sebagai informan telah memenuhi beberapa kriteria dalam menghadapi segala tantangan dengan selalu mengamalkan nilai-nilai kebenaran. (5) Memiliki prinsip kesatuan. Prinsip kesatuan di dalam pemahaman komitmen merupakan sebuah penentuan arah pada pendirian pribadi kehidupan sosial seseorang secara teguh, maupun menjaga akidah dalam menjalankanpekerjaannya dengan senantiasa bertawakal kepada Allah SWT. Hal tersebut dapat dijelaskan melalui prinsip kesatuan para kedelapan informan pedagang pasar muslim krembangan yang selalu bersegera memenuhi panggilan Allah ketika waktu ibadah tiba 
Ayunirraga, et al/Jurnal Ekonomi Syariah Teori dan Terapan Vol. 3 No. 7 Juli 2016: 533-548; PERAN KOMITMEN DALAM MENGHINDARI IHTIKAR SEMBAKO di PASAR KREMBANGAN SURABAYA (Studi Pada Mahasiswa Program Studi Ekonomi Islam Fakultas Ekonomi dan Bisnis Universitas Airlangga)

disela-sela kesibukan pekerjaannya dalam melayani pembeli, Menjaga tali silaturahmi sesama pedagang dengan mengadakan berbagai kegiatan sosial antar warga pedagang pasar krembangan, dan melakukan kajian pendalaman kerohanian antar pedagang muslim dengan pengurus masjid besar Krembangan Surabaya. Para informan pada umumnya memahami dan menjalankan peran dari sebuah prinsip kesatuan yang merupakan salah satu wujud komitmen berperilaku akan menjaga pribadinya di hadapan Allah dari tindakan yang dapat merugikan dirinya sendiri, maupun orang lain. Melayani pelanggan sebaik mungkin merupakan suatu bentuk pengabdian para informan kepada pekerjaannya secara sungguhsungguh dengan penuh tanggung jawab, karena para informan beranggapan bahwa tindakan penimbunan kebutuhan bahan pokok pada umumnya dapat terjadi, karena pribadi tersebut tidaklah mengabdikan pekerjaannya secara penuh tanggung jawab dalam menjalankan (jatuh ataupun bangun) usahanya. Seluruh informan dapat menjelaskan tentang pemahaman dan penerapan salah satu bentuk dari komitmen berperilaku yang prinsip kesatuan (tauhid) dalam berdagang, sehingga menjaga perilaku mereka sesuai dengan aturan Allah SWT.

Hasil dari penelitian ini masih memiliki banyak kekurangan dan sangat jauh dari kata sempurna. Banyak keterbatasan dan halangan yang dialami oleh peneliti, ketika berda dilapangan. Penyebab keterbatasan waktu dalam penelitian, keterbatasan tempat dan obyek penelitian membuat peneliti sedikit mengalami kesulitan dalam mengembangkan penelitian, perbedaan latar belakang pendidikan informan yang berbeda-beda, sehingga sering menyebabkan kesalahpahaman dalam mengeksplorasi pertanyaan kepada informan. Peneliti sedikit terbantu akan beberapa arsip dan perijinan penelitian terhadap induk pengelola PD Pasar Surya yang menaungi pengelolaan Pasar Krembangan Surabaya. Para pedagang Muslim yang membuka toko induk sembako hanya berjumlah 8 orang, dan selebihnya adalah tidak memenuhi kriteria penelitian juga merupakan halangan yang dialami oleh peneliti, tetapi dengan dedikasi dan kerja keras dapat diatasi dengan hasil eksplorasi wawancara tentang kehidupan sosial dan spiritualitas para informan secara menyeluruh tentang komitmen dalam menghindari penimbunan bahan pokok di Pasar Krembangan Surabaya.

\section{SIMPULAN}

Berdasarkan analisis dan pembahasan yang telah dijelaskan pada Bab 4, maka dapat diperoleh simpulan sebagai berikut:

1. Para pedagang muslim Pasar krembangan surabaya pada umumnya memahami tentang pentingnya memiliki sebuah komitmen sebagai bentuk dasar berperilaku 
Ayunirraga, et al/Jurnal Ekonomi Syariah Teori dan Terapan Vol. 3 No. 7 Juli 2016: 533-548; PERAN KOMITMEN DALAM MENGHINDARI IHTIKAR SEMBAKO di PASAR KREMBANGAN SURABAYA (Studi Pada Mahasiswa Program Studi Ekonomi Islam Fakultas Ekonomi dan Bisnis Universitas Airlangga)

berdagang yang baik dalam ajaran Islam.

2. Para pedagang muslim Pasar Krembangan Surabaya pada umumnya telah merasakan dampak tuntunan berdagang dalam ajaran Islam secara baik pada meningkatnya produktivitas pedagang itu sendiri. Selanjutnya akan berdampak pada kinerja para pedagang muslim Pasar Krembangan Surabaya dalam mengembangkan usahanya sendiri.

3. Para pedagang muslim Pasar Krembangan Surabaya pada umumnya telah memahami komitmen berdagang dalam Islam sesuai yang dikemukakan oleh Anwar (2007:32-38) yaitu niat ikhlas (sosial), kerja keras, kesatuan (tauhid), kebenaran (keadilan), dan kebebasan berkehendak dalam kegiatan berdagang di Pasar Tradisional Krembangan Surabaya.

4. Wujud komitmen perilaku Islami dalam bisnis yang dikemukakan oleh Anwar (2007:32-38) pada umumnya sesuai dengan pemahaman para pedagang muslim Pasar Krembangan Surabaya.

Berdasarkan hasil pengamatan peneliti kepada pedagang sembako muslim Pasar Krembangan Surabaya, saran yang dapat diberikan dalam penelitian ini adalah sebagai berikut:

a. Bagi pedagang Sembako Muslim

Dari pemahaman pentingnya komitmen untuk menghindari penyimpangan dalam berdagang, dalam hal ini adalah penimbunan (ikhtikar) para pedagang, sebaiknya diadakan kegiatan sosial dan rohani antar pedagang untuk lebih mengenal aturan agama mengimplementasikan dalam mencegah para pedagang untuk berbuat penyimpangan berdagang.

b. Bagi Penelitian Selanjutnya

Penelitian ini memiliki banyak keterbatasan dan kekurangan, sehingga bagi para peneliti selanjutnya yang akan melakukan penelitian dalam topik yang berkaitan tentang penimbunan (ikhtikar), diharapkan dapat meneliti topik yang lebih mendalam mengenai kaidah fiqih tentang ikhtikar dengan alat ukur dan kriteria yang lebih terfokus terhadap kualitas dan realibilitas kehidupan sosial para pedagang pasar muslim. Hasil dari penelitian ini diharapkan dapat membantu penelitian selanjutnya untuk memberikan sumbangsih kepada pengetahuan masyarakat.

\section{DAFTAR PUSTAKA}

Alamsyah, A.A. 2001. Data Jumlah dan Kelas Pasar Tradisional di Wilayah Jawa Timur. Jakarta: Bina Marga

Ali, Munjit. 2000. Fiil Loghat. Islamic: Economic. Malaysia. Journal of Economic Research, 4, 23. 
Ayunirraga, et al/Jurnal Ekonomi Syariah Teori dan Terapan Vol. 3 No. 7 Juli 2016: 533-548; PERAN KOMITMEN DALAM MENGHINDARI IHTIKAR SEMBAKO di PASAR KREMBANGAN SURABAYA (Studi Pada Mahasiswa Program Studi Ekonomi Islam Fakultas Ekonomi dan Bisnis Universitas Airlangga)

Anwar, Syamsul. 2007. Hukum Perjanjian Syariah: Studi tentang TeoriAkad dalam Fiqh Muamalah. Jakarta: Rajawali Pers. As-Sayyid Mahmud Hawari. 1976. Al Idarah: Al Asasul wal Ushulil Ilmiyyah. Cairo. Med. Sci., cet. III. no. 16. pp. 198.

Elly, M.J. 2009, Sistem Informasi Geografis Indonesia. Yogyakarta: Graha IImu.

Ibrahim, Muhammad, Al-Jamal. 1986. kaidah fiqih. Semarang: Asy Syifa.

Harindyatama, Febvania, Irma. 2013. Kejujuran Pedagang Muslim Dalam Timbangan dan Kualitas Beras Di Pasar Bendul Merisi Surabaya. Pascasarjana UNAIR Surabaya.

Huzaimah. 1997. Problematika Hukum Islam Kontemporer. Jakarta: LSIK.

Munawar, Ismail. 1997. Islam Kapitalisme dan Sosialisme, Studi Komperatif Sistem Ekonomi, Jurnal Lintasan Ekonomi, Edisi khusus Januari-April. Malang: Lembaga Penerbit FE Unibraw.

Naqvi, Syed Nawab. 1993. Etika dan IImu Ekonomi Suatu Sintesis Islami. Bandung: Mizan.

Partina, CW. 2005. The_New Global Competitive Environment: business planned behavior. Washington (DC). National Academies., vol 17, no.9. pp. 1284.

Rahman, Afzalul. 1995. Doktrin Ekonomi Islam. Yogyakarta: PT. Dana Bhakti Wakaf.

Sudarsono, Heri. 2000. Konsep Ekonomi Islam. Yogyakarta: CV Adipura.
Sugiyono. 2010. Metode Penelitian Kuantitatif Kualitatif dan $R$ \& $D$. Bandung: Alfabeta.

Syafi'i, Rahmat. 2006. Fiqih Muamalah untuk UIN, STAIN, PTANIS, dan Umum. Bandung: Pustaka Setia.

Syaikh Abdurrahman. 2007. The Effects of Islamic Organizational and Ethical Climate as on Misconduct at Work. Journal of Business Ethics. Cairo. ABII Global. Vol. 31. No. 1889. 